Любомир Белей *

Ужгородський національний університет

Філологічний факультет

Кафедра української мови
UDC: $811.163 .1: 811.161 .2 ' 36$

DOI: $10.19090 /$ gff.2017.1.23-33

Прегледни научни рад

\title{
СТАРОСЛОВ'ЯНСЬКИЙ СЛІД В УКРАЇНСЬКІЙ ТА ІНШИХ СЛОВ’ЯНСЬКИХ ЛІТЕРАТУРНИХ МОВАХ
}

Перша літературна мова слов'ян - старослов'янська мова мала особливий вплив на літературні мови всіх слов'янських народів, однак іiі вплив на кожну 3 нових літературних мов слов'янських народів був суто індивідуальним, що знаходило свій вияв у часі, тривалості, причинах та формах такого впливу. В історії української мови тривалий час, особливо в період СССР, вивчення ролі старослов'янізмів перебувало на маргінесі наукових інтересів мовознавців. Натомість наше дослідження виявляє глибинний характер впливу старослов'янської мови, тісно пов'язаної 3 християнських віровченням. Приховані старослов'янські сліди в сучасній українській мові можна відшукати не лише у сфері церковно-обрядової лексики: побут, наука, навіть астрологія, 3 якою християнство споконвіку веде безкомпромісну боротьбу, мають чимало прихованих старослов'янізмів, більшість із яких фіксують уже перші старослов'янські пам'ятки української редакції.

Ключові слова: старослов'янська мова, старослов'янізм, псевдостарослов'янізм, фонетична адаптація, лексична система української мови.

Старослов'янська мова як перша літературна мова слов'ян мала великий вплив на літературні мови всіх слов'янських народів, а також і на окремі неслов'янські мови, наприклад румунську, носії якої також сповідують християнство східного обряду. Однак вплив старослов'янської мови на кожну 3 нових літературних мов слов'янських народів не був стереотипним, а радше суто індивідуальним, що знаходило свій вияв у часі, тривалості, причинах та формах такого впливу. Звичайно, літературні мови слов'янських народів, що сповідують християнство східного обряду (болгари, македонці, серби, українці, росіяни, білоруси), були під більшим впливом старослов'янської писемності, ніж мови тих слов'ян, що сповідують християнство західного обряду або протенстантизм (словінці, хорвати, чехи, словаки, поляки, верхні лужичани, нижні лужичани). Більше того, навіть на такі близькоспоріднені мови, як українська та російська, словенська та хорватська або чеська та

\footnotetext{
*dlyamene@gmail.com
} 
нижньолужицька, старослов'янська мова впливала по-різному: у різний час, за різних культурно-історичних обставин, на різних структурних рівнях мов.

Коли розглядати проблему впливу старослов'янської мови на сучасні слов'янські мови, то треба наголосити, що тут болгарська та македонська мови посідають особливе місце, оскільки вони справедливо, хоч і 3 певними застереженнями, вважаються прямими спадкоємцями старослов'янської літературномовної традиції. Адже саме болгаро-македонські діалекти послужили, як відомо, діалектною основою старослов'янської мови, це особливо помітно на іï фонетичному та морфологічному рівнях. Що стосується інших слов'янських народів, то, попри все, старослов'янська мова не була для них рідною (а це не завжди і не сповна усвідомлювали самі мовці), а тому специфіка її впливу у випадку кожної слов'янської літературної мови була суто індивідуальною та визначалася цілою низкою чинників як екстралінгвальної, так і інтралінгвальної природи.

Так, наприклад, відомий російський мовознавець А. Шахматов іще на поч. XX ст. заявляв, що «російська літературна мова - це русифікована церковнослов'янська (тобто старослов'янська. - Л. Б.)». На підтвердження цієї тези А. Шахматов називає дванадцять безсумнівних фонетичних, граматичних, лексичних рис старослов'янської мови, які притаманні і для російської літературної мови, та узагальнює, що «на підставі здійсненого аналізу церковнослов'янізмів у сучасній літературній мові видно, що іiі словниковий склад щонайменше наполовину, якщо не більше, залишився церковнослов'янський» (Шахматов, 1941: 90).

Показово, але ще наприкінці XIX ст. Ф. Міклошич у «Краткомъ словаре шести славянскихъ языковъ (русскаго съ церковнославянскимъ, болгарскаго, сербскаго, чешскаго и польскаго), а также французскій и немһцкій»...» (1885) подає разом російські та церковнослов'янські слова.

Позицію А. Шахматова підтримував відомий американський славіст Б. Унбегаун, а Л. Щерба взагалі заявляв, що близько 2/3 лексикону російської літературної мови так або інакше треба пов'язувати з лексико-семантичною системою старослов'янської мови. Гіпотеза Шахматова-Унбегауна була піддана гострій критиці з боку російських «патріотичних» учених, зокрема С. Обнорського та Ф. Філіна. Проте навіть за їхніми підрахунками у сучасній російській літературній мові нараховується 26123 церковнослов'янізми, що становить приблизно $20 \%$ iï лексичного запасу (Филин, 1978: 413). Якщо порівнювати питому вагу старослов'янізмів у російській та українській або білоруській літературних мовах, то, наприклад, за такою досить показовою 
рисою, як повноголосся/неповноголосся східнослов'янські мови суттєво відрізняються одна від одної. За підрахунками А. Фідровської, «у білоруській та українській мовах кількість повноголосних коренів, що допускають неповноголосні форми, становить менше ніж четвертину слів 3 повноголоссям, тоді як у російській мові їх більше половини» (Фидорковская, 1961: 140).

Висока питома вага старослов'янізмів у сучасній російській літературній мові пояснюється впливом цілої низки чинників, серед яких окремо варто виділити так званий другий південнослов'янський вплив, що розпочався у др. пол. XIV ст. і виявлявся на теренах тогочасної Московії у масовому усуненні російських живомовних впливів з богослужбових книг та ретельному виправленні їх до первісного болгаро-македонського стандарту. Виконавцями цієї акції були численні представники сербського та болгарського духовенства, які після підкорення їхніх рідних країв турками (1389 р. поразка сербів на Косовому полі та підкорення Болгарського царства 1393 р.) знайшли собі прихисток у православній Московії. На теренах сучасних України та Білорусі, попри присутність і тут болгаро-сербського духовенства, так званий другий південнослов'янський вплив був малопомітний, бо сильнішою була місцева писемна традиція.

В українському мовознавстві, зокрема совєтської доби, роль та місце старослов'янізмів у системі української літературної мови розглядалася, як правило, дуже поверхово та схематично, а не раз такий аналіз хибував на вульгарно-соціологічні оцінки, оскільки на старослов'янській мові лежало тавро мови церкви, 3 якою ідеологи СССР вели непримиренну боротьбу. Часто усе зводилося до переліку структурних фонетико-граматичних ознак старослов'янізмів та констатації, що використовують їх у поетичному мовленні 3 метою надати оповіді урочистості. Показово, але навіть у академічній «Історії української мови. Лексика і Фразеологія» аналіз старослов'янізмів не виокремлено і проводиться він лише принагідно.

Ще менше уваги старослов'янізмам приділяють лексикологи західнослов'янських мов. Наприклад, словацький мовознавець П. Ондрус навіть не виокремлює їх в окрему групу, а лише називає близько двох десятків старослов'янізмів, кваліфікуючи їх то поетичними словами, то біблеїзмами (Ondrus, 1972: 39-40).

Перелік структурних ознак старослов'янізмів в українській мові усталений. Це так зване неповноголосся (врата, злато, брег); звукокослолуки жд (вождь, страждати); ініціальне $\epsilon$ - (єдність); і/менникові суфікси -юнь-, ств-, -тель, -ин'-, -тв-, -тай (приязнь, мислитель, братство, гординя, битва, 
глашатай); дієприкметникові суфікси -ащу-, -ущ-, -м- (роботящчий, грядущуий, знайомий); префікси воз-, пре-, пред-, со- (возз'єднаний, предтеча, премудрий, соратник); композити, одним із компонентів яких є благо-, бого-, добро-, зло(благодать, богогласник, добродійство, злорадство). 3 лексичних старослов'янізмів називають крест (хрест), ланіти, уста, священик тощо (Сучасна українська літературна мова 2005: 128). Попри свій значний обсяг, це далеко не повний перелік структурно-семантичних ознак старослов'янізмів, 3 якого випали, наприклад, утворення 3 префіксом без-, численні семантичні кальки. Не треба також забувати, що саме старослов'янська мова виступила, наприклад, посередником при запозиченні українською мовою звука [ф], якого, як відомо, не було у праслов'янській мові. Завдяки старослов' янським словам акафисть, альфа, анафема, антифонъ, афини, африкии, фараонъ, фарисеи, фелонъ, фесалоникиянинъ, философия, философъ, фимиянъ, фимияница, финикъ, фаворъ, фесалоники, фадеи, феодоръ, феона, фекъла, феона, феофанъ, феокътистъ, феодосии, феодотъ, ферапонтъ, фома, филипъ, фимофеи та ін. звукова система української мови поповнилася новим звук [ф].

У сфері лексики роль старослов'янських елементів була набагато помітнішою, а в окремих випадках старослов'янізми не мали альтернативи в питомо українському лексиконі. Найсильніші позиції старослов'янська мова мала, звичайно, у сфері сакрально-церковної лексики, що й цілком очікувано 3 огляду на їі статус офіційної чи канонічної мови християнського культу східного обряду. Тому переважна більшість сакрально-церковної лексики української мови - від загальновживаних амвон, апостол, архиєрей, вівтар, диякон, єпископ, іконостас, митрополит, літургія, піп, плащаниця, хрест, церква та ін. аж до вузьких теологічно-обрядових термінів на зразок антимінс, апракос, дискос, глас, мінея, ірмологіон, стихира, типікон, хиротонія та багато ін. - була запозичена зі старослов'янської мови або потрапила в українську за їі посередництвом.

Завдяки тому, що старо-/церковнослов'янська мова для українців, як зрештою і для більшості слов'янських народів, стала мовою християнського культу та християнського віровчення, то ¥ї вплив на українську мову не обмежився лише сферою сакрально-церковної лексики. Так, старослов'янська мова стала посередницею при запозиченні українцями в часі хрещення РусіУкраїни звичних нині християнських імен. Завдяки старослов'янським джерелам протягом XI-XIII ст. на Русь-Україну потрапило близько чотирьох сотень християнських імен (Белей, 2010: 45). Зазначимо, що посередництво 
старослов'янської мови при запозиченні староєврейських, грецьких чи латинських 3 походження християнських імен не було пасивним: адже саме у старослов'янських текстах чужомовна форма цих імен була слов'янізована, тобто адаптована до звукової та морфологічної будови слов'янських мов. Так, гербейські Yõchãnãn та'ēl iliàhu старослов'янська мова адаптує в іоаннъ та

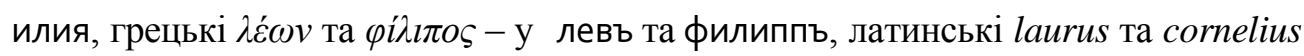
- у лавръ та корнилии та ін. Зважаючи на виняткову важливість особових імен в українському лексиконі (адже вони існують у десятках, окремі навіть у сотнях варіантів, від них утворюють прізвища, прізвиська, топоніми, а також чимало загальних назв), роль старослов'янської мови як посередника у формуванні цього розряду власних назв годі переоцінити. Старослов'янське походження мають також традиційні вже для української мови назви християнських свят: Благовіщення (благовһштение), Богоявлення (богоявлһние), Великдень (великъ дьнь), Преображення (преображение), Різдво (рождьство), Трійия (троица), Успіння (оуспение) та ін.

Глибинний характер впливу старослов'янської мови, тісно пов'язаної 3 християнських віровченням, яскраво простежується на українських назвах днів тижня: звичні для кожного українця неділя, понеділок, вівторок, середа, четвер, n’ятниця, субота постали на базі старослов' янських назв недһля, понедһльникъ, срһда, въторъникъ, або въторъкъ, четврьть, п\#тъкъ, с@бота. Відзначимо, що творцям старослов'янських текстів у назвах днів тижня вдалося дивовижним чином не лише віддзеркалити засади християнського світобачення, а й поєднати канони Старого та Нового Заповітів. 3-поміж семи назв тижня лише одна гебрейська 3 походження - c๔бота-cубота, яка за Старозаповітною традицією називає останній, сьомий день тижня, день відпочинку, вільний від роботи. За Новозаповітною традицією центральним стає також вільний відроботи день недһля-неділя, який уславив своїм воскресінням Ісус Христос, тому саме від цього дня йде відлік днів тижня. Ця суто зовнішня, формальна колізія щодо визначення «справжнього» дня відпочинку має, як відомо, переконливе теологічне роз'яснення, проте щоб уникнути суто формальних, тобто мовних, суперечностей у назвах днів тижня, творці старослов'янських назв днів тижня знайшли геніальне розв'язання цієї проблеми - називаючи «зайвий» вихідний день, вони віддали перевагу чужомовній назві, первісне значення якої для слов’ ян було затемнене, і в такий спосіб «утаємничили», що й субота - вільний від роботи день. Так за посередництвом старослов'янської мови серед українських назв днів тижня 3'явилася непрозора 3 погляду первісного 
значенням «вільного від роботи дня» назва сєбота-субота, що цілком відповідає Старозаповітній традиції. Назва ж першого, також вихідного дня, але вже за канонами Нового Заповіту, віддзеркалює семантично прозора назва недһля-неділя: не-ділати, тобто не працювати.

Приховані старослов'янські сліди в сучасній українській мові можна відшукати не лише у сфері церковно-обрядової лексики: побут, наука, навіть астрологія, 3 якою християнство споконвіку веде безкомпромісну боротьбу, мають чимало прихованих старослов'янізмів, більшість із яких фіксують уже перші старослов'янські пам'ятки української редакції. Наприклад: азбука (азъбоукы), буква (боукы), вертеп (вьртьпъ), злаки (злакъ), планета (від планить), тварина (тварь), Близнята (близьньць), Водолій (водолһиць), Козеріг (козьльрогъ), Лев (левъ), Овен (овьнъ), Рак (ракъ), Риби (рыба), Скорпіон (скорпиосъ), Стрілецьь (стрһльць), Тілецьь (тһлець) та ін.

Оцінюючи впливи старослов'янської мови на українську, важливо пам'ятати, що цілу низку так званих старослов'янізмів 3 виразними південнослов'янськими фонетичними рисами було створено давньоукраїнськими перекладачами, переписувачами та редакторами старослов’ янських рукописів XI-XIII ст., а окремі з них постали навіть у XX ст. До числа таких псевдостарослов'янізмів українського походження зараховують влас\#ниця '«волосяниця», плать «оплата», отрокъ «підліток», схранити «поховати», скомрахъ «скоморох», драгоцһньнъ '«коштовний», младость «молодість», влатъ «волот», клаколь «дзвін»; пор. «колокол», мраморь «мармур»; пор.: «мороморъ» (Львов, 1975: 8; Цейтлин, 1977: 23). Ці факти $\epsilon$ свідченням співтворчості українських книжників у творенні старослов' янської писемності .

За підрахунками вчених, приблизно 50 \% старослов'янських лексем позначають абстрактні поняття та дії й процеси, пов'язані з ними, які були невідомі ні предкам сучасних українців, ні інших слов'янських народів, а тому їх створювали перекладачі та редактори старослов'янських текстів. Не випадково авторські старослов'янізми, які за своєю природою мають панслов'янський характер, на зразок віра, вірити, душогуб, злословити, книжник, надія, невіглас, невірство, ненависть, несила, неправда, неприязнь, питомий, подруга (у ст.-сл.: подроугъ), послух, причасник, пророк, рукопис (пор. ст.-сл.: р®кописание), священик, самовидецьь, стовпотворіння, творець тощо вписалися в лексичну систему української мови і не виказують свого чужомовного походження. Механізм творення так званих псевдостарослов'янізмів української мови можна простежити на прикладі 
загальновживаного іменника всесвіт. За спостереженнями В. Німчука, іменник всесвіт, ймовірно, створив проф. Є. Тимченко на базі церковнослов'янського словосполучення вьсь свһmъ, яке читали як весь світ. Від нього постало незручне для вимови складне слово весьсвіт, яке $€$. Тимченко трансформував у звичне всесвіт (Німчук, 1992: 18). Поява українського слова всесвіт, яка датується 20-pp. XX ст., показує, що й тепер старослов'янська писемність не втрачає своєї вітальної сили.

Втім, ресурси старослов'янської писемності в сучасній українській літературній мові використовують украй обмежено. В Україні серед філологів, а ще більшою мірою серед широкої культурницької громадськості міцно утвердилися хибні погляди на старослов'янську мову як на явище чуже, неукраїнське за походженням та сутністю, а тому питома вага церковнослов'янізмів у лексичній системі сучасної української літературної мови має бути мінімалізована (Белей, 1999: 87-88).

Упереджене ставлення до старослов'янізмів в українській мові, окрім уже згадуваного атеїстичного, спричиняється ще двома чинниками. У середовищі консервативної філологічної громадськості, на виховання якої мали вплив ідеї російського (українського) «класного патріотизму», визнання впливу старослов'янської мови чомусь безпідставно трактують як приниження ролі та статусу російської або української мов. Натомість серед українських ультрапатріотів поширене хибне переконання, яке дуже влучно сформулювала одна 3 учасниць Всеукраїнської наукової конференції «Сучасна українська богословська термінологія: від історичних традицій до нових концепцій» (Львів, 1999): «тепер для культурної людини (!!! -Л. Б.) церковнослов’янізм сприймається як русизм».

Штучне звуження погляду на старослов'янізми в українській мові як на суто чужомовне явище, а також вивчення їхніх структурних ознак та загальне окреслення стилістичних функцій затінює важливу проблему - роль старослов'янської мови як посередника в міжмовних контактах давньоукраїнської мови доби Середньовіччя або вплив старослов'янської писемної традиції на формування української літературної мови. При традиційній оцінці місця та ролі старослов'янізмів в українській літературній мові замовчують той факт, що після християнізації Русі-України старослов'янська мова стає першою і спершу єдиною літературною мовою українців, які були не лише «споживачами» старослов'янської писемності, а й активними іiі творцями. Відомий український філолог Д. Чижевський подає цілий список старослов'янських перекладів, уперше здійснених саме на теренах 
Русі-України, - «тлумачення листів апостола Павла та "Пісні Пісень", книга Есфірі, "Пролог”, житія - Андрія Юродивого, Стефана Сурозького, Федора Студита, чудеса Миколи Чудотворця, деякі - Дмитра Солунського, Кузьми та Дам'яна в Корсуні, Георгія, проповіді Федора Студита, "Посланіє" Петра Антіохійського, оповідання про перенесення мощів Миколи Чудотворця в Барі, Студійський Устав, Пандекти Никона Чорногорця...» (Чижевський, 1994: 72).

Уже лише сам факт створення цих пам'яток на теренах Русі-України та численні українські риси їх мови дають вагомі підстави зараховувати ці тексти до набутків української духовної культури. Українці мають велику заслугу перед усім слов'янським світом за збереження та примноження кириломефодіївських традицій у добу великої руїни південного слов'янства та суцільної латинізації західного.

Старослов'янізми були і залишаються невід'ємним і часто досить помітним стилетворчим елементом української літературної мови. Особливий статус старослов'янізмів у лексичній системі української літературної мови донаціональної доби забезпечувався завдяки таким чинникам: 1) близькоспорідненості солунсько-македонського та давньоукраїнських діалектів; 2) авторській, а тому панслов'янській природі значного числа старослов'янізмів; 3) системній адаптації старослов'янізмів до фономорфемної структури української мови. Досить згадати геніальну Шевченкову «Марію», щоб розвіялися всякі сумніви у неукраїнськості численних Шевченкових старослов'янізмів:

Все упованіє моє

На тебе, мій пресвітлий раю,

На милосердіє твоє,

Все упованіє моє

На тебе, мати, возлагаю.

Святая сило всіх святих!

Пренепорочная, благая!

Воззри, Пречистая, на їх

Отих окрадених сліпих

Невольників. Подай їм силу

Твойого мученика сина,

Щоб хрест-кайдани донесли

До самого, самого краю!

Достойно петая! Благаю!

Цариия неба $і$ землі!

Вонми їх стону і пошли 
Благий конецьь, о всеблагая!

А я, незлобний, воспою,

Як процвітуть убогі села,

Псалмом і тихим і веселим

Святую доленьку твою.

А нині плач, і скорбь, і сльози

Душі убогої - убогій

Останню лепту подаю.

Таким чином, переоцінка місця і ролі старослов'янської мови в історії української літературної мови - актуальне завдання сучасної україністики. Адже, як слушно писав Ю. Шевельов ще в 1950 р., «ми вже давно переросли етнографізм, ми усвідомили українськість усього понадетнографічного в нашій історії: Київської і Литовсько-Руської Держави, греко-болгарської (3 походження) Церкви, старої нашої, не народньою мовою писаної літератури, а отже - і церковнослов'янізмів. Відмовлятися від них - означає якоюсь мірою відмовлятися від нашої історії в ім'я нібито позаісторичної, сталої етнографії. На це може піти етнографічна маса, але не нація» (Шевельов, 2012: 470).

Белей Любомир

\section{THE OLD CHURCH SLAVONIC TRACES IN UKRAINIAN AND OTHER LITERARY SLAVIC LANGUAGES}

\section{Summary}

Old Church Slavonic was the first Slavic literary language and had special influence on the literary languages of all Slavic people; however, this influence on each of the new Slavic literary languages was rather specific, which can be observed in the time, duration, reasons and forms of such an influence. During a long period in Ukrainian history, especially during the time of the Soviet Union, the research into the role of the vocabulary of Old Church Slavonic origin was highly neglected by the scholars. On the contrary, our research shows the depth of the influence of the Old Church Slavonic language that is highly intertwined with Christianity. In the Ukrainian language, the hidden Old Church Slavonic traces can be found not only in the vocabulary related to the church and its customs, but also in the language connected with everyday life and science. Moreover, despite the long-lasting fight between Christianity and astrology, even here we can find many hidden examples of the vocabulary which is Old Church Slavonic in origin, which were mostly fixed in the first examples of Ukrainian editorials.

Keywords: Old Church Slavonic language, vocabulary of Old Church Slavonic origin, pseudo-vocabulary of Old Church Slavonic origin, phonetic adaptation, lexical system of the Ukrainian language 
Љубомир Белеј

\section{СТАРОСЛОВЕНСКИ ТРАГ У УКРАЈИНСКОМ И \\ У ДРУГИМ СЛОВЕНСКИМ КЮИЖЕВНИМ ЈЕЗИЦИМА \\ Сажетак}

Први књижевни језик - старословенски језик је имао посебан утицај на књижевне језике свих словенских народа, али ипак његов утицај на сваки од нових књижевних словенских језика био је потпуно индивидуалан, што се показивало у времену, трајању, разлозима и облицима таквог утицаја. У историји украјинског језика је дуго, нарочито за време СССР-a, изучавање улоге старословенизама било на маргини научних интересовања лингвиста. Међутим, наше истраживање показује суштинске особине утицаја старословенског језика, тесно повезане са хришћанском религијом. Скривени старословенски трагови у савременом украјинском језику могу се пронаћи не само у сфери црквено-обредне лексике: свакодневни живот, наука, чак и астрологија, са којом хришћанство од памтивека води бескомпромисну борбу, имају много заједничких скривених старословенизама, од којих већи део фиксирају већ први старословенски споменици украјинске редакције.

Кључне речи: старословенски језик, старословенизам, псеудостарословенизам, фонетска адаптација, лексички систем украјинског језика.

\section{DZHERELA I LITERATURA}

Beley, Lyubomyr (1999). Ukrayins'ka bohoslovs'ka terminolohiya: shlyakhy rozvytku. Suchasnist’. - № 12., 87-88. (Rad objavljen ćirilicom!)

Beley, Lyubomyr (2010). Ukrayins'ki imena kolys' i teper. - K.: Tempora, 45. (Rad objavljen ćirilicom!)

Chyzhevs'kyy, Dmytro (1994). Istoriya ukrayins'koyi literatury. Vid pochatkiv do doby realizmu. - Ternopil', 72. (Rad objavljen ćirilicom!)

Fydorkovskaya, Anna (1961). O polnohlasnыkh y nepolnohlasnыkh formakh $\mathrm{v}$ belorusskom y ukraynskom yazыkakh // Pamyaty V. A. Bohorodytskoho. Kazan', 140. (Rad objavljen ćirilicom!)

Fylyn, Fedot (1978). Yskonnoe y zaymstvovannoe v sovremennom rusckom lyteraturnom уаzыke // Slavyanskoe yazыkoznanye. VIII Mezhdunarodnыy sъezd slavystov. - Moskva, 413. (Rad objavljen ćirilicom!)

L'vov, Andrey (1975). S. Leksyka «Povesty vremennokh let». - Moskva, 8. (Rad objavljen ćirilicom!)

Nimchuk, Vasyl' (1992). Davn'orus'ka spadshchyna v leksytsi ukrayins'koyi movy.-K., 18. (Rad objavljen ćirilicom!)

Ondrus, Pavel (1972). Slovenská lexikológia. - Bratislava, 39-40.

Shakhmatov, Aleksey (1941). Ocherk sovremennoho russkoho lyteraturnoho yazыka. - Moskva, 90. (Rad objavljen ćirilicom!) 
Shevel`ov, Yurij (2012). Neviddil`na spadshhy`na (kil`ka sliv pro ukrayins`ki cerkovnoslov'yanizmy`) // Nary`s suchasnoyi ukrayins`koyi literaturnoyi movy` ta inshi lingvisty`chni studiyi (1947-1953).- K.: Tempora, 470. (Rad objavljen ćirilicom!)

Suchasna ukrayins'ka mova (2005). Za red. M Plyushch. - K., 128. (Rad objavljen ćirilicom!)

Tseytlyn, Ralya (1977). Leksyka staroslavyanskoho yazыka... Moskva, 23. (Rad objavljen ćirilicom!) 